\title{
ポスト石油時代における 生物資源の役割
}

第6部対外報告と研連活動から—

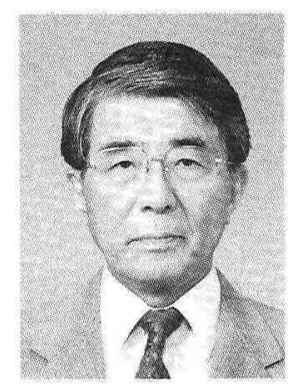

上野 民夫

\section{生物資源の再評価}

21 世紀の半ばには到来が予測される食糧危機 と資源の枯渴に対して、環境問題と同様に我々 は現在から十分な配慮と対策を講じて㧍く必要 がある。このことに対して第6部ではすでに第 16 期から、農業生産の強化のための基盤整備に とどまらず、生物資源の有効利用の重要性につ いていくつかの研連において先駆的なシンポジ ウムが企画され検討が加えられてきた。

一方、1997年12月に京都で開催された「気候 変動枠組み条約第3回締約国会議」において二酸 化炭素の排出削減に向けて国際的な条約の締結 が試みられたことは、6部内での討議に大な影響 を及ぼした。

その結果、農業の特性である二酸化炭素の固 定能と循環的生物資源生産能を再評価し、二酸 化炭素濃度の低減と地球温暖化の回避に向けて 積極的に生物資源の生産と有効利用を推進する 方策の検討が始まった。その成果は第17期の第 6部の活動に反映され、発醉学・農産物利用学、 生物工学、木材学と農業機械学の 4 研究連絡委 員会を中心に部会での討論とシンポジウムを経 て、その内容は「生物資源とポス卜石油時代の 産業科学一生物生産を基盤とする持続・循環型
社会の形成をめざして一」と題する第6部対外報 告にまとめられている。

そこに記された内容は「地球環境を保全しつ つ、人類社会を持続的に繁栄させるためには、 太陽エネルギーの固定によって生産される生物 資源に依存するポスト石油社会に移行する必要 がある」と要約できる。

\section{新ライフスタイル産業の 創出と生物資源}

第17期教育·環境問題特別委員会からの声明 の背景と補足説明は「21世紀半ばに到来が必至 とされる資源・エネルギ一消費の限界と人口増 加との矛盾を克服するためには、脱「物質・エネ ルギー志向」に基づく新しい価值観への転換と新 ライフスタイル産業の創出と振興を提示してい る。これを受けて、先に掲げた第6部対外報告 「生物資源とポスト石油時代の産業科学一生物生 産を基盤とする持続・循環型社会の形成をめざ してー」は、持続的な人類社会の繁栄と環境の 保全を目指してこの新ライフスタイル産業創出 に向けての具体的方策を提言している。

その要点は、1）植物は太陽エネルギーを化学 エネルギーに変換して蓄積したバイオマスを循 環的に生産している。2) 発酵法やバイオテクノ 
ロジーを駆使して、未利用農産廃棄物から有用 物質への効率的転換を図る。3）植物と微生物に よる二酸化炭素の固定能を向上させるための研 究を推進する。4）生物資源の高度利用による物 質生産を達成するには、「カスケード的に最も効 率よく利用する」ための生産管理システムを構 築する必要がある。5）枯渴が到来するリン資源 (植物の 3 大栄養素の一つ) 回収システムを確立 する。6) 生物資源の地域多様性に応じた多様な 利用形態を開発する。

光合成によって毎年生産されるバイオマス $2 \times$ $10^{11} \mathrm{t}$ 中の炭素は約 $8 \times 10^{10} \mathrm{t}$ で、エネルギーでは $300 \times 10^{19} \mathrm{~J}$ に相当する。これは現在の全世界に おける化石燃料由来の年間総エネルギー消費量 $30 \times 10^{19} \mathrm{~J}$ の10倍に相当することを考えると、太 陽エネルギーと生物資源に依存する持続・循環 型社会の形成は、21世紀に打ける新ライフスタイ ルの構築に向けて十分な合理性を提供している。

\section{地域研究の重要性}

けれども、生物資源は地域と環境に依存し、 生産の確保と利用には極めて多様なアプローチ を必要とすることは容易に想定できるところで ある。このことから、生物資源を基盤とする産 業の創出には、地域に密着した学術研究による 多面的解析と統合・俯瞰的な生産システムの構 築が求められる。

このため、第6部ではまず生物資源を基盤とす る地域産業創出の前提として、発酵学・農産物
利用学研究連絡委員会などが主体となって、地 域に密着した生物資源の多様性とその維持保存 に向けての方法論を展開する。それとともに具 体的に研究推進を図るために、平成11年11月に 鹿児島市で「熱帯・亜熱帯の生物資源の多様性 とその維持保存」と平成12年11月には札幌市で 「北方の作物・魚・森林一その遺伝資源の有効利 用の現状と将来展望一」と題するシンポジウム を開催し、生物資源を基盤とする地域産業の創 出に向けての活動を開始した。

すでに行われた鹿児島のシンポジゥムでは、 種の絶滅に起因する生物の多様性の喪失を回避 するために、ジーンバンクと微生物の菌株の収 集と保存の有用性が指摘された。1993年12月に 発効した「生物多様性条約」に基づく生物資源 に対する原産国の主権を、1999年1月現在です でに175力国が批准していることを考慮すると、 今や遺伝資源の帰属は国際的に極めて重要な問 題を包含していることがわかる。このことを考 えると政府は早急にジーンバンクの整備を支援 すべきと考える。

上野民夫（うえの たみお 1938年生） 日本学術会議第6部会員、発酵学・農産物利用学研究連絡 委員会委員、化学研究連絡委員会農芸化学・応用化学専 門委員会委員、近畿地区会議代表幹事、学術のあり方常 置委員会幹事、京都大学大学院農学研究科教授、京都大 学評議員

専門：生物有機化学、天然物有機化学、農薬化学 